\title{
Comparative Study of Development between Islamic Inheritance Law According to Compilation of Islamic Law (KHI) \& Faroid Science
}

\author{
Ninuk Tri Welas *) \\ *) Students of Master of Notary Law, Faculty of Law, Universitas Islam \\ Sultan Agung (UNISSULA) Semarang
}

\begin{abstract}
The background of this research explains that the Islamic Inheritance Law regulates the matters of inheritance (inheritance) left by the deceased, namely regulating the transfer of inheritance from the deceased (heir) to the living (heir). This study uses an empirical juridical approach, with descriptive analytical specifications of data collected with primary data from field research and secondary data from literature studies, while qualitative data. This research in: (1) Forms of inheritance law that have not been contained in conventional figh (figh almawarits), but they have been contained and codified in the KHI inheritance law, including: Article 171 concerning Joint Assets, Article 177 concerning the division of fathers 'asobah. Article 209 states that adoptive fathers and adopted children receive an inheritance, and if they do not receive a will, then they are entitled to receive a compulsory will. (2) Comparison of Islamic Inheritance Law according to the Compilation of Islamic Law (KHI) with Faroid Science, namely: Indonesia as a developing country which is developing requires uniformity (unification) of law in the form of codification (Written Law). (3) Similarities and Differences in Islamic Inheritance Law According to the Compilation of Islamic Law (KHI) and Faroid Science, which should be used as the main reference in the framework of drafting a Law on KHI. Indonesia as a developing country which is developing requires uniformity (unification) of law in the form of codification (Written Law). (3) Similarities and Differences in Islamic Inheritance Law According to the Compilation of Islamic Law (KHI) and Faroid Science, which should be used as the main reference in the framework of drafting a Law on KHI. Indonesia as a developing country which is developing requires uniformity (unification) of law in the form of codification (Written Law). (3) Similarities and Differences in Islamic Inheritance Law According to the Compilation of Islamic Law (KHI) and Faroid Science, which should be used as the main reference in the framework of drafting a Law on KHI.
\end{abstract}

Keywords: Islamic Inheritance Law; Islamic Law Compilation; Faroid Science. 


\section{Introduction}

The implementation of Islamic law in Indonesia, in brief, has undergone a long phase since the Dutch colonial era until this time of change. History proves that the application of Islamic law in an Indonesian order has only been applied in Act No. 1 of 1974 concerning marriage and in Act No. 7 of 1989 regarding the judiciary even with tiring struggles, especially for Muslims. $^{1}$

Islamic inheritance law is an important expression of Islamic family law, it is half the knowledge possessed by humans as emphasized by the Prophet Muhammad SAW. Studying and studying Islamic inheritance law means studying half of the knowledge possessed by humans who have been and continue to live in the midst of Muslim society from the early days of Islam to medieval times, modern and contemporary times and in the future. ${ }^{2}$ Since its early history (origin) to its formation and development (change and development) in the contemporary era, Islamic inheritance law shows the dynamics and developments that are important to be studied and researched by observers of Islamic law. It is not a coincidence that many observers have written and studied the development of Islamic inheritance law from various aspects.

The contact of Islam with various religions that existed from the early days of Islam to the contemporary era has also colored the relationship between Islam and non-Islam (read: Muslims and non-Muslims). It even colored Islamic law in its relations with non-Muslims, including Islamic inheritance law. The inheritance of different religions is one of the contemporary problems in contemporary Islamic legal thought. The problem of the inheritance of different religions emerged when Muslim and non-Muslim relations were again discussed and discussed by various groups. In fact, this has been the concern of Islamic thinkers from its inception to the

\footnotetext{
1 Abdul Gani Abdullah, 1992, Pengantar Kompilasi Hukum Islam dalam Tata Hukum Indonesia, Gema Insani Press, Jakarta, p. 35.

2 N. D. Anderson, Hukum Islam Di Dunia Modern, terj. Machnun Husein (Surabaya: Amarpress, 1991), p. 66
} 
contemporary era. ${ }^{3}$ It's just that the demands of the contemporary era in which there are issues of relations between religions and human rights force again to discuss the inheritance of different religions in the perspective of Islamic law.

Efforts to reform in the form of codification and unification of law, especially civil law such as inheritance, munakahat, and so on, appeared when the Compilation of Islamic Law was born in Indonesia. These laws have changed both in legal status and in practice. KHI is stated in Presidential Instruction No.1 of 1991, and implemented by Decree of the Minister of Religion Number 154 of 1991. According to Islamic law experts such as Rachmat Djatnika, Abdul Gani Abdullah, Bustanul Arifin, and others, $\mathrm{KHI}$ is a positive Islamic law to implement regulations. Current regulation. It has consistency with laws and regulations of a higher position and is used as a reference for law enforcers. ${ }^{4}$

Changes in law both the implementation of Islamic law pre $\mathrm{KHI}$ and after $\mathrm{KHI}$. Furthermore, if one looks at the process of legal change contained in the $\mathrm{KHI}$, it cannot be separated from the characteristics of the change itself. In this case, legal changes include legal systematics, legal materials and legal methods. At the level of legal systematics, changes in law, according to Fazlur Rahman's view, ${ }^{5}$ has a threefold approach:

1. A simple and honest historical approach in finding the meaning of the Qur'anic text. First of all, the Qur'an must be examined in chronological order by examining its earliest revelations, then;

2. Distinguish between the legal dictum of the Qur'an, the goals and objectives of the law.

3. The goal of the Qur'an must be understood, mixed, and paid attention to the sociological setting in which the Prophet moved and worked.

\footnotetext{
${ }^{3}$ Mun'im A.Sirry (ed.), Fiqih Lintas Agama: Membangun Masyarakat Inklusif Pluralis, (Jakarta: Yayasan Wakaf Paramadina, 2004), p. 18

4 Cik Hasan Bisri, 1996, Dimensi-dimensi Kompilasi Hukum Islam, Ulul Albab Press, Bandung, p. 13.

${ }^{5}$ Fazlur Rahman, Islam (Terj.), (Bandung: Salman ITB, 1994), p. 67.
} 
Changes in the study of material in $\mathrm{KHI}$ in this study are in the field of inheritance (Book II). Basically this inheritance material is a transition and even a renewal of the form of Islamic inheritance law which is very well known among the jurists. The forms of inheritance change in the Islamic Law Compilation include:

1. Article 171 sub e regarding joint assets. In this article, it is revealed that collective property is separate from each other's personal assets. Even in polygyny marriages-serial marriages, the form of shared property is separate between the husband and each wife. Meanwhile, in the Qur'an and Al-Hadith, there is no definite text of this problem.

2. Article 177 concerning the father's part. In this article it is formulated that the father gets $1 / 3$ of the share if the heir does not leave the child. But if there are children, then the father gets $1 / 6$ of the share. The provisions of this article are not contained in the Qur'an (surah an-Nisa: 11) and the ulama's ijma which determines the father's part by way of ashobah if the deceased does not leave children. Articles 183-184 regarding peace in the distribution of inheritance and the appointment of guardians.

3. Article 183 allows for the distribution of inheritance in equal portions (1: 1) between boys and girls, which deviates from Article 176 which regulates the provisions of boys and girls.

4. Article 189 concerning maintenance of the integrity and integrity of land with an area of less than 2 (two) hectares, in order to maintain its original integrity.

Whereas for heirs who need money or capital, this can be done by replacing part of the inheritance he gets. This distribution pattern actually contradicts the principle of ljbari. According to Amir Syarifudin, expressing the principle of ljbari means that the transfer of property rights from one muwarits to another (heirs) applies independently according to Allah's provisions without depending on the will of muwarits or heirs. Based on the background of the above problems, the writer is interested in formulating the following problems:

1. How is the development of Islamic inheritance law in the Compilation of Islamic Law?

2. How is the comparison of Islamic inheritance law according to the Islamic Law Compilation (KHI) with the science of Faroid? 
3. How are the similarities and differences in Islamic inheritance law according to the Islamic Law Compilation (KHI) with the science of Faroid?

\section{Research Methods}

The method used in this research based on three types of approaches, namely the statutory approach, the historical approach and the conceptual approach. The statutory approach is carried out by examining the laws and regulations related to this research, then linked to the issues to be discussed, the historical approach is carried out by examining the background of the problems raised in this research and the conceptual approach is carried out when the researcher does not move from the rule of law existing, for example not or there is no legal rule for the issues raised. This study uses an empirical juridical approach, with descriptive analytical specifications of data collected with primary data from field research and secondary data from literature studies, while qualitative data.

\section{Results and Discussion}

3.1. The development of Islamic inheritance law in the Compilation of Islamic Law

In the Islamic Law Compilation (KHI) it is stated that "Inheritance law is a law that regulates the transfer of ownership rights to the inheritance (tirkah) of the inheritor, determines who has the right to become heirs and how much of each share. The two definitions of inheritance law above are basically sufficient. ${ }^{6}$ Thus to formulate it as follows: "The law of inheritance is a law that regulates the transfer of ownership of the inheritance (tirkah) of the heir, determines who has the right to become heirs, determines how much share of each heir, and regulates when to distribute the inheritance's assets. It was implemented.

The forms of inheritance law development in the Islamic Law Compilation include:

1. Article 171 sub e which reads "Inheritance is the inheritance plus part of the joint assets after being used for the benefit of the heir during illness until death, the cost of managing the corpse (tajhiz), paying the debt and giving it to relatives. "In this article, it is revealed that

${ }^{6}$ Ibid, p. 108 
shared assets are separate from each other's personal assets. Even in polygyny-serial marriages, the form of shared assets is separated between the husband and the foreign wife.

2. Article 176, among other things, states that a son's share of inheritance is two to one that of a girl. However, Article 299 (which is a closing provision) states that in resolving cases submitted to him, judges are obliged to pay serious attention to legal values that live in society so that their decisions are in accordance with the sense of justice. And this has often been done by Indonesian courts, by not implementing the distribution of inheritance based on the principle that sons receive two shares while women are one. ${ }^{7}$

3. Article 177 concerning the father's part. In this article it is formulated that the father gets $1 / 3$ of the share if the heir does not leave the child. But if there are children, then the father gets $1 / 6$ of the share. The provisions of this article are not contained in the al-Qur'an (surah al-Nisa: 11) and the ulama's ijma which determines the father's portion by means of 'asobah if the deceased does not leave a child.

4. Article 184 regarding peace in the distribution of inheritance. This article opens the opportunity for the distribution of inheritance in equal portions (1: 1 ) between boys and girls, which deviates from Article 176 which regulates the provisions of boys and girls.

5. Article 184 concerning the appointment of a guardian.

6. Article 185 concerning successor heirs. If the term "Substitute Inheritance" is intended to appoint a non-heir to become an heir, then it is clear that this is contrary to Islamic inheritance law which is based on ljbari. ${ }^{8}$

7. Article 189 concerning maintenance of the integrity and unity of agricultural land with an area of less than 2 (two) hectares, in order to maintain its original unity. Meanwhile, for heirs who need money / capital, this can be done by changing the price of a portion of the inheritance they receive. This distribution pattern actually contradicts the principle of ljbari. Amir Syarifudin revealed that the principle of ljbari implies that the transfer of property rights from one muwarits to another (heir) applies independently according to Allah's provisions without depending on the will of muwarits or heirs.

8. Article 209 states that adoptive fathers have the right to inherit the inheritance of their adopted children. Likewise, on the other hand,

\footnotetext{
${ }^{7}$ Munawir Sjadzali, ljtihad Kemanusiaan, (Jakarta: Paramadina, 1997), p. 224

${ }^{8}$ Amrullah Ahmad, SF.Dkk, Op.Cit, p. 63
} 
adopted children have the right to inherit the inheritance from their adoptive father. If they do not receive a will, they will be given a mandatory will not exceeding $1 / 3$ of the inheritance of the child / adoptive parent. In fact, in Islamic law, no child and adoptive parents receive an inheritance.

9. Islamic inheritance law in Indonesia recognizes the Gono-Gini institution, whereas Islamic law does not exist. ${ }^{9}$

$\mathrm{KHI}$ brought about quite an important change regarding the inheritance system which has been adopted by Muslim communities in Indonesia in general using books derived from the Sunni school of thought which adheres to the patrilinier inheritance system. ${ }^{10}$ Meanwhile, the inheritance system adopted by $\mathrm{KHI}$ is as stated in QS An-Nisa (4): 7 and 11, namely the bilateral inheritance system. According to this system, sons or grandchildren of daughters (zawi al arham) are both the heirs of asobah zawi al furud, so they are not entitled to inherit. In the KHI, if all heirs are present, only children, fathers, mothers, widows or widowers are entitled to inherit. In this article, the word child is called absolutely without the explanation of male / female. This means that if there are children, regardless of whether they are boys or girls, then the heir's siblings or uncle are the heirs. Meanwhile, according to conventional jurisprudence, if the child is a girl then it can only wear hijab nuqsan or reduce the share of the heirs asobah. ${ }^{11}$

In general, the scholars state that the age of adulthood is fulfilled if a person is fifteen years old and / or has sperm for men and has been 9 years old or has menstruated for women. Meanwhile, the elderly are under the age of adulthood. The next update occurred in the provisions of Article 195 paragraph (2) KHI which states that a will must be made in the presence of two witnesses or a notary, either verbally or in writing. This provision is not found in the figh books. The scholars of figh did not include the provision of two witnesses for the validity of a will. They stipulate that wills have four

\footnotetext{
${ }^{9}$ Munawir Sjadzali, Op.Cit, p. 225

${ }^{10}$ Imron AM, Hukum Kewarisan dan Hibah dalam Kompilasi Hukum Islam, Mimbar Hukum, No. 24, Tahun 1996, p. 45

${ }^{11}$ Alimuddin, Kompilasi Hukum Islam Sebagai Hukum Terapan Bagi Hakim Pengadilan Agama, (Makassar: Alauddin University Press, 2011), p. 75.
} 
pillars, namely the testament to the recipient of the will, the inherited object and sighat and qabul. ${ }^{12}$

The next renewal occurs in the provisions of Article 197 paragraph (1) KHI which states that the recipient of the will is obstructed if; first, to kill, try to kill or seriously maltreat the testator; second, slander the testator that the testator has committed a crime with a sentence of five years or more; third, by force and threats, prevent the testator from making or withdrawing or changing the will for the benefit of the beneficiary.

Adopted children, $\mathrm{KHI}$ does not clearly explain that according to Islamic law adopted children do not inherit from their adoptive parents, and vice versa, but can get inheritance by other means. However, on the other hand, the adopted child is a person who has a special humanitarian relationship in terms of closeness and mutual assistance as well as the placement of his status in the family by his adoptive parents as like his own family (own child). ${ }^{13}$ Therefore, it is only natural when $\mathrm{KHI}$ accommodates giving to adopted children whose adoptive parents died earlier or vice versa, who did not receive a will, then the inheritance (tirkah) is given through the wăjibah will by providing a limit not exceeding one third of the inheritance of the adoptive parents or his adopted son. However, there are also those who argue that adopted children and adoptive parents still cannot result in a mutual inheritance relationship, even though by means of a compulsory will. Adoptive parents and adopted children may receive a share of the inheritance by means of a grant. This method may be accepted because the grant can be made to anyone, including adoptive parents and adopted children.

\subsection{Comparison of Islamic Inheritance Law according to the Compilation of Islamic Law (KHI) with Faroid Science}

In the $\mathrm{KHI}$, the provisions regarding inheritance are regulated in Book II, which consists of 23 articles, from Article 171 to Article 193. In these various provisions there are several things that are not in classical fiqh, but are in the KHI, as well as provisions that should exist, but not included in the KHI. The provisions referred to include:

\footnotetext{
${ }^{12}$ Al-Zahir, Ibnu Hazm, al-Muhalla Darul-Fikr, Beirut, p. 278-286.

${ }^{13}$ Alimuddin, Op.Cit, p. 78
} 
a) The proportion of male and female shares is maintained in accordance with the argument of the Qur'an, namely that the male portion is twice the female share;

b) There is a principle of deliberation in the distribution of inheritance (Article 183), that experts can agree to make peace in the distribution of inheritance after each realizes their share;

c) Distribution of the inheritance does not have to physically share the object.

Article 189 regulates the distribution of inheritance in the form of agricultural land with an area of less than 2 hectares which must be maintained and utilized jointly or by paying the price of the land so that the land remains in the possession of an heir only; There are several conditions that must be fulfilled in the distribution of inheritance. These conditions always follow the pillars, but some are independent. In this case the writer finds three inheritance conditions that have been agreed upon by the scholars, these three conditions are:

1. The death of someone (the heir) either haqiqi, hukmy, (for example, is considered dead) or taqdiri.

2. There are heirs who live haqiqi life when the heir dies.

3. All heirs are known for their exact parts. ${ }^{14}$

In the Complications of Islamic Law, there are three kinds of heirs, namely:

1. Dzawil Furud

2. Ashobah

3. Mawali

The forms of inheritance development in the Islamic Law Compilation include:

1. Article 171 sub e which reads "Inheritance is the inheritance plus part and joint assets after being used for the needs of the heir during illness until death, the cost of managing the corpse (tajhiz), payment of debts and gifts to relatives."

2. Article 176 states that a son's share of inheritance is two to one that of a girl. However, Article 229 (which is the closing provision) states

\footnotetext{
${ }^{14}$ Muhammad Ali Ash Abuni, al Mawaris Fisy Syari'atil Islamiyyah 'Ala Dhani' al Kitab wa Sunnahlm. Terj. A.M. Basalamah "Pembagian Waris Menurut Islam", (Jakarta: Gema Insane Press, 1995), p. 33
} 
that in settling the cases submitted to him, the judge is obliged to pay serious attention to the legal values that live in society so that his decision is in accordance with the sense of justice.

3. Article 177 concerning the father's part. In this article it is formulated that the father gets $1 / 3$ of the share if the heir does not leave the child. But if there are children, then the father gets $1 / 6$ of the share.

4. Article 183 concerning peace in the distribution of inheritance. This article opens the opportunity for the distribution of inheritance in equal portions (1: 1$)$ between boys and girls, which deviates from Article 176 which regulates the provisions of boys and girls.

5. Article 184 concerning the appointment of a guardian.

6. Article 185 concerning successor heirs.

Although this is clearly not intended to appoint a non-heir to be an heir, because of course this is against Islamic inheritance law which is based on ljbari.

1. Article 189 concerning maintenance of the integrity and unity of agricultural land with an area of less than 2 (two) hectares, in order to maintain its original unity. Whereas for heirs who need money or capital, this can be done by changing the price of a portion of the inheritance he gets.

2. Article 209 states that adoptive fathers have the right to inherit the inheritance of their adopted children. Likewise, on the other hand, adopted children have the right to inherit the inheritance from their adoptive father.

3. Islamic inheritance law in Indonesia recognizes the Gono-Gini institution, whereas Islamic law does not exist. ${ }^{15}$

From the development of Islamic Law Compilation and Comparison of inheritance law in Islamic Law Compilation with inheritance law in conventional fiqh, it can be because:

1) Indonesia as a developing country that is developing requires uniformity (unification) of law in the form of codification (Written Law) as an implication of the existence of the judiciary.

2) Changing times and the need of Indonesian society towards legal certainty that will be followed. Taghayurul ahkam bitaghayuril azminah wal amkinah wal awal'id. The affirmation of figh principles

${ }^{15}$ Munawir Sadzali, Op.Cit, p. 225. 
as the basis for the need for legal changes that are local to Indonesian in nature.

3) So that the inheritance law in the $\mathrm{KHI}$ can be used as applied law (material) for Command agencies (Religious Courts) and the Indonesian people in resolving inheritance cases.

\subsection{Similarities and Differences in Islamic Inheritance Law According to the Compilation of Islamic Law (KHI) with Faroid Science}

In Islamic law there are twenty-five heirs who are entitled to inheritance, with details of fifteen from the male side and ten from the female side. ${ }^{16}$

a. Male heirs are sons, grandchildren of sons, fathers, grandfathers, siblings, brothers of the same father, brother of a mother, son of a brother The son of a single sibling, the son of the same brother, the uncle of the same, the uncle of the same father, the son of the same brother, the son of the same uncle, the son of the same husband, and the man who has freed the slave's slave.

b. The female heirs are daughters, granddaughters of sons, mothers, paternal grandmothers, maternal grandmothers, siblings, brothers of a father's sister, a thousand sisters, wives, and women who have freed their slave servants.

The fifteen male heirs, if together they become heirs, only three of the heirs continue to receive a share, namely: sons, fathers and husbands. Whereas from the female side, if together they become heirs, the heirs who still receive the inheritance are only five people, namely: daughter, granddaughter of son, mother, sibling sister and wife. And when all heirs gather, both men and women, only five people are entitled to inheritance, namely husband / wife, sons, daughters, father and mother.

According to Islamic inheritance law, the size of each relative's inheritance is based on the degree of their kinship. Therefore, the stronger relatives got more. In fact, not all relatives will inherit, because the rights owned by some relatives will arise if there are certain relatives. This has been clearly regulated in the Qur'an and as-Sunnah. In Article 171 of the Compilation of Islamic Law, there are several provisions regarding this inheritance,

16 Asrory zain Muhammad dan Mizan, Al-faraidh (Pembagian Pusaka dalam Islam), 
namely: Inheritance law is a law that regulates the transfer of ownership of inheritance (tirkah) inheritance, determines who has the right to become heirs and how many parts of each. The heir is a person who, at the time of his death, is Muslim, leaving an heir and inheritance.

An heir is a person who at the time of death has a blood or marital relationship with the heir, is Muslim and is not hindered by law to become an heir. Inheritance is property left by the heir, either in the form of property which is his property or his rights. Inheritance is the inheritance plus part of the joint assets after being used for the needs of the heir from illness to death, the cost of managing the corpse, paying off debts and giving to relatives.

A will is the gift of an object from the heir to other people or institutions that will take effect after the heir dies. A grant is the giving of an object voluntarily and without reward from someone to another person who is still alive to have.

According to Islamic law, inheritance rights are given to the woman's family (daughters, grandchildren, mother and grandmother of the woman, sister of one thousand, one father or one thousand only). The number of heirs is 25 people, consisting of 15 from the male side and 10 from the female side. The male heirs are:

a. Son (al ibn).

b. Grandson, namely boys and so on down (ibnul ibn).

c. Father ( $a l a b)$.

d. Grandfather, namely the father of the father (al jad).

e. One thousand brothers and sisters (al akh as syqiq).

f. One brother's brother (al akh liab).

g. A thousand brothers (al akh lium).

h. A thousand brother's nephew (ibnul akh as syaqiq).

i. Farher's nephew (ibnul akh liab).

j. One thousand uncle.

k. Uncle sibling (al ammu liab).

l. A thousand male cousin (ibnul ammy as syaqiq).

m. One male cousin (ibnul ammy liab).

n. Husband (az zauj).

o. A man who frees, means a person who frees a servant if I don't have an heir.

Meanwhile, the female heirs are: 

a. Daughter (al bint).
b. Granddaughter (bintul ibn).
c. Mother (al um).
d. Grandmother, namely her mother (al jaddatun).
e. Grandmother from the father's side (al jaddah minal $a b$ ).
f. A thousand sisters of a father (al ukhtus syaqiq).
g. Sister from dad (al ukhtu liab).
h. Sister from mom (al ukhtu lium).
i. Wife (az zaujah).
j. Women who liberate (al mu'tiqah).

Heirs are people who are entitled to inherit. ${ }^{17}$ So that there are three conditions to become an heir specified in Article $171 \mathrm{c} \mathrm{KHI}$, namely: ${ }^{18}$

1. People who are related by blood or marital relations with the heir.

2. Islam is a religion.

3. Not prevented by law from becoming the heir.

This can be seen in Article $172 \mathrm{KHI}$ which reads that the heir is considered to be Muslim if it is known from the Identity Card or confession or practice or testimony, while for newborns or children who have not yet matured, the religion according to their father or environment. In the article above, it will be seen that one of the reasons for someone to be an heir is a Muslim. Because the article shows how to show someone's Islamic status as a cause of inheritance and is the main condition for obtaining an inheritance. Still in the discussion of $\mathrm{KHI}$, the reasons for inheriting in the form of kinship or blood relations will be seen in Article 174 a. and because of the marital relationship in Article $174 \mathrm{~b}$.

In the $\mathrm{KHI}$ there is also an explanation of the class of heirs and the size of the section is described in Articles 172 - 193. An heir must be Muslim and the heir is considered Muslim if it is known from an identity card or a confession or practice or testimony stating that he is Muslim. Meanwhile,

${ }^{17}$ Zainuddin Ali, Pelaksanaan Hukum Waris Di Indonesia, (Jakarta: Sinar Grafika, 2010), p.

47

${ }^{18}$ Compilation of Islamic Law, p. 114 
for newborns or children who are not yet mature, they have religion according to their father or environment $(172 \mathrm{KHI}) .{ }^{19}$

Inheritance are various rules regarding the transfer of property rights of a deceased person to their heirs. In other terms, inheritance is also called Faroid, which means a certain part which is divided according to Islam to all who are entitled to receive it. ${ }^{20}$

The heirs in the compilation of Islamic law (KHI), can inherit if they have a cause and fulfill the conditions.

a. The reasons are:

1) Have a religious relationship or blood relationship

2) Have a marital relationship.

b. The conditions are:

1) The heir lives when the heir dies.

2) Islam is a religion

3) Has no inheritance barrier.

The group of heirs in the compilation of Islamic law (KHI) as stated in Article 174 paragraph (1) letter a is the same as the group of heirs in the previous inheritance books and figh books.

\section{Closing}

1. The development of Islamic inheritance law in the Compilation of Islamic Law includes many elements of customary law and the interests needed by Indonesian society today. So there are many forms of inheritance law that have not been contained in conventional fiqh (fiqh almawarits), but they have been contained and codified in the $\mathrm{KHI}$ inheritance law, including: Article 171 concerning Joint Assets, Article 177 concerning the distribution of fathers as 'asobah. Article 209 states that adoptive fathers and adopted children receive an inheritance, and if they do not receive a will, then they are entitled to receive a compulsory will. And $\mathrm{KHI}$ also acknowledges this Gono-Gini institution even though classical figh does not admit it (does not make it a sub-discussion).

\footnotetext{
19 Ibid., p. 115

${ }^{20}$ Beni Ahmad Saebani, Fiqh Mawaris, (Bandung: Pustaka Setia, 2009), p. 13
} 
2. The comparison of inheritance law in the Islamic Law Compilation with inheritance law in conventional figh can be because:

a. Indonesia as a developing country that is developing requires uniformity (unification) of law in the form of codification (Written Law) as an implication of the existence of the judiciary.

b. Changing times and the need of Indonesian society towards legal certainty that will be followed. Taghayurul ahkam bitaghayuril azminah wal amkinah wal awal'id. The affirmation of figh principles as the basis for the need for legal changes that are local to Indonesian in nature.

c. So that the inheritance law in the KHI can be used as applied law (material) for Command agencies (Religious Courts) and the Indonesian people in resolving inheritance cases.

3. Similarities and Differences in Islamic Inheritance Law According to the Compilation of Islamic Law (KHI) with Faroid Science, which should be used as the main reference in the framework of drafting a Law on $\mathrm{KHI}$, while the difference, if it cannot be compromised, can also be used as complementary material in the form of doctrines. Which can be chosen to fill the void, considering that $\mathrm{KHI}$ is unlikely to be able to provide a complete solution in the sense of compiling completely all issues of Islamic inheritance law in Indonesia.

\section{References}

Journals:

[1] Alimuddin, 2011, Kompilasi Hukum Islam Sebagai Hukum Terapan Bagi Hakim Pengadilan Agama, (Makassar: Alauddin University Press.

[2] Imron AM, Hukum Kewarisan dan Hibah dalam Kompilasi Hukum Islam, Mimbar Hukum, No. 24, Tahun 1996

[3] Mun'im A.Sirry (ed.), 2004, Fiqih Lintas Agama: Membangun Masyarakat Inklusif Pluralis, (Jakarta: Yayasan Wakaf Paramadina. 
[4] Muhammad Ali Ash Abuni, 1995, al Mawaris Fisy Syari'atil Islamiyyah 'Ala Dhani' al Kitab wa Sunnahlm. Terj. A.M. Basalamah "Pembagian Waris Menurut Islam", Jakarta: Gema Insane Press.

Books:

[1] Abdul Gani Abdullah, 1992, Pengantar Kompilasi Hukum Islam dalam Tata Hukum Indonesia, Gema Insani Press, Jakarta

[2] Asrory zain Muhammad dan Mizan, 1981, Al-faraidh (Pembagian Pusaka dalam Islam, Surabaya: Bina Ilmu, Surabaya.

[3] Beni Ahmad Saebani, 2009, Fiqh Mawaris, Bandung: Pustaka Setia.

[4] Cik Hasan Bisri, 1996, Dimensi-dimensi Kompilasi Hukum Islam, Ulul Albab Press, Bandung.

[5] Fazlur Rahman, 1994, Islam (Terj.), Bandung: Salman ITB.

[6] Munawir Sjadzali, 1997, ljtihad Kemanusiaan, Jakarta: Paramadina.

[7] N. D. Anderson, 1991, Hukum Islam Di Dunia Modern, terj. Machnun Husein Surabaya: Amarpress.

[8] Zainuddin Ali, 2010, Pelaksanaan Hukum Waris Di Indonesia, Jakarta: Sinar Grafika.

Regulation:

[1] Presidential Instruction of the Republic of Indonesia Number 1 of 1991 concerning Dissemination of Compilation of Islamic Law

[2] Decree of the Minister of Religion of the Republic of Indonesia Number 154 of 1991 concerning Compilation of Islamic Law and Act No 1 of 1974 concerning Marriage 
[3] Act No 1 of 1974 concerning Marriage

[4] Act No 7 of 1989 concerning Judiciary 